\title{
Contribution of GABAergic interneurons to amyloid- $\beta$ plaque pathology in an APP knock-in mouse model
}

\author{
Heather C. Rice 1,2,3, Gabriele Marcassa ${ }^{1,2}$, lordana Chrysidou ${ }^{1,2}$, Katrien Horré ${ }^{1,2}$, Tracy L. Young-Pearse ${ }^{4}$, \\ Ulrike C. Müller ${ }^{5}$, Takashi Saito ${ }^{6,7}$, Takaomi C. Saido $^{6}$, Robert Vassar ${ }^{8}$, Joris de Wit ${ }^{1,2^{*}}$ and Bart De Strooper ${ }^{1,2,9^{*}}$ (D)
}

\begin{abstract}
The amyloid- $\beta$ (AB) peptide, the primary constituent of amyloid plaques found in Alzheimer's disease (AD) brains, is derived from sequential proteolytic processing of the Amyloid Precursor Protein (APP). However, the contribution of different cell types to $A \beta$ deposition has not yet been examined in an in vivo, non-overexpression system. Here, we show that endogenous APP is highly expressed in a heterogeneous subset of GABAergic interneurons throughout various laminae of the hippocampus, suggesting that these cells may have a profound contribution to AD plaque pathology. We then characterized the laminar distribution of amyloid burden in the hippocampus of an APP knockin mouse model of AD. To examine the contribution of GABAergic interneurons to plaque pathology, we blocked $A \beta$ production specifically in these cells using a cell type-specific knock-out of BACE1. We found that during early stages of plaque deposition, interneurons contribute to approximately $30 \%$ of the total plaque load in the hippocampus. The greatest contribution to plaque load (75\%) occurs in the stratum pyramidale of CA1, where plaques in human $A D$ cases are most prevalent and where pyramidal cell bodies and synaptic boutons from perisomatic-targeting interneurons are located. These findings reveal a crucial role of GABAergic interneurons in the pathology of AD. Our study also highlights the necessity of using APP knock-in models to correctly evaluate the cellular contribution to amyloid burden since APP overexpressing transgenic models drive expression in cell types according to the promoter and integration site and not according to physiologically relevant expression mechanisms.
\end{abstract}

Keywords: Alzheimer's disease, Amyloid precursor protein, Amyloid plaques, APP knock-in, GABAergic neurons, Interneurons, GABA receptor, Hippocampus, BACE1

\section{Background}

The biochemical phase of Alzheimer's disease (AD) is characterized in part by the accumulation and aggregation of the neurotoxic amyloid- $\beta(A \beta)$ peptide [27], which is generated by sequential proteolytic processing of the Amyloid Precursor Protein (APP). This leads to the complex cellular phase of $\mathrm{AD}$, which involves feedback and feedforward responses of multiple cell types [27]. Distinguishing the contribution of specific cell types to $A \beta$ deposition may provide key insights into the interrelationships between the longstudied biochemical phase and the cellular phase of $\mathrm{AD}$. Excitatory neurons, which generate $A \beta$ in an activity-

\footnotetext{
* Correspondence: joris.dewit@kuleuven.vib.be;

bart.destrooper@kuleuven.vib.be

${ }^{1}$ VIB Center for Brain \& Disease Research, Leuven, Belgium

Full list of author information is available at the end of the article
}

dependent manner $[4,12]$, have long been considered the primary source of $A \beta$ deposition in the brain. However, subtypes of fast-spiking GABAergic interneurons are highly active compared to excitatory neurons [7, 13], Moreover, a recent study indicates that cells other than excitatory neurons are a major source of $A \beta$ deposition in a transgenic model of AD [29]. This study was however limited by the fact that APP expression was driven by an artificial prion promoter. Contrary to the long-held perception that APP is a ubiquitously expressed protein, regional and cell-type specific differences of endogenous APP expression, including a striking expression pattern in GABAergic interneurons, have been observed in the mouse hippocampus by us and others [28, 31]. Moreover, GABAergic interneurons were found to be overrepresented in subpopulations of cells that secrete high levels of $A \beta$ in a study that measured $A \beta$

(c) The Author(s). 2020 Open Access This article is distributed under the terms of the Creative Commons Attribution 4.0 International License (http://creativecommons.org/licenses/by/4.0/), which permits unrestricted use, distribution, and 
secretion with single-cell resolution from cultured human induced pluripotent stem cell-derived neurons and glia [16].

To circumvent the influence of APP overproduction and mis-patterning, APP knock-in mouse models in which APP is expressed under its endogenous promoter with a humanized $A \beta$ sequence and familial $A D$ mutations have been generated $[23,24]$. These $A p p^{N L-G-F}$ knock-in mice provide an ideal model to study the contribution of APP expression in GABAergic interneurons of the hippocampus to $A \beta$ generation in mice.

\section{Results}

APP is prominently expressed in a subset of hippocampal interneurons

App mRNA is relatively evenly distributed across Vgat1positive inhibitory neurons and Vglut1-positive excitatory neurons in the hippocampus of 5-week old wild type mice (Additional file 1: Figure S1). However, immunohistochemistry of APP (anti- c-terminal APP, B63) in the hippocampus of 5 week-old wild type mice (Fig. 1a) supports a previous report that the distribution of APP protein is prominent in GABAergic interneurons of the hippocampus [14]. There is also strong diffuse staining within the stratum lacunosum-moleculare (SLM) of Cornu Ammonis 1 (CA1). In the CA1 subfield (Fig. 1b), the majority (approximately $60 \%)$ of the APP-immunoreactive interneurons resides at the border between the stratum radiatum (SR) (Fig. 1c-d), which receives input from Schaffer collaterals of the CA3 region, and the SLM, which receives input from the entorhinal cortex (Fig. 1b). Approximately 20\% of the APPpositive interneurons are located within the stratum oriens (SO) (Fig. 1d), where basal CA1 dendrites reside. We surveyed the neurochemical profile of these APP-positive interneurons (Fig. 1e). Within the SR and SLM, 47\% of APP-positive interneurons are Reelin-positive, 32\% are Cholecystokinin (CCK)-positive, and 27\% are Calbindinpositive (Fig. 1e). Within the SO, 41\% of APP-positive interneurons are Parvalbumin-positive (Fig. 1e). However, not all interneurons are immunoreactive for APP. Within the SR and SLM, none of the Calretinin-positive cells are APPpositive, and only $35 \%$ of Reelin-positive cells and $61 \%$ of Calbindin-positive cells are immunoreactive for APP (Fig. 1e). Within the SO, very few of the Somatostatinpositive cells are APP-positive (8\%) and $53 \%$ of the Parvalbumin-positive cells are APP-positive (Fig. 1e). CCKpositive cells had the greatest overlap with APP-positive cells, with $95 \%$ of CCK-positive cells being also APPpositive across all CA1 laminae (Fig. 1e). Together, we observe that APP has striking expression in a heterogeneous subset of interneurons.

The prominent APP expression in a subset of interneurons suggests that APP function may be important in these cell types. Therefore, we examined the co- expression of APP with $\gamma$-aminobutyric acid type B receptor subunit $1\left(\mathrm{GABA}_{B} \mathrm{R} 1\right)$ (Fig. 1e), which functionally interacts with the APP ectodomain to regulate presynaptic inhibition $[5,22]$ and is reported to label a neurochemically heterogeneous subset of interneurons [26]. All APP-positive cells at the SR/SLM border (100\%) and in the $\mathrm{SO}(100 \%)$ are $\mathrm{GABA}_{\mathrm{B}} \mathrm{R} 1$-positive (Fig. 1f). Conversely, at the SR/SLM border $97 \%$ of $\mathrm{GABA}_{\mathrm{B}} \mathrm{R} 1$-positive cells are APP-positive, and in the $\mathrm{SO} 70 \%$ of $\mathrm{GABA}_{\mathrm{B}} \mathrm{R} 1$ positive cells are APP-positive (Fig. 1f). These findings indicate that the heterogeneous population of APPpositive interneurons strongly but not completely coexpresses its functional binding partner, $\mathrm{GABA}_{\mathrm{B}} \mathrm{R} 1$.

\section{Laminar distribution of amyloid plaques in the hippocampus of an APP knock-in mouse model}

The striking expression of APP in specific interneuron populations suggests that these interneurons might be major contributors to $A \beta$ pathology in the hippocampus. Therefore, we analyzed plaque distribution in the $A p p^{N L-G-F}$ knock-in mouse model [23]. We performed VGLUT1 immunostaining to segment the laminae and WFS1 immunostaining to distinguish CA1 from CA2/3 subfields (Fig. 2a, Additional file 2: Figure S2). Masks for $\mathrm{A} \beta$ plaques were created based on $\mathrm{A} \beta$ immunostaining (6E10 antibody; Fig. 2a) and combined with the regions of interests for each of the subfields and laminae to quantify $A \beta$ plaque load by percent area (Fig. 2b, Additional file 2: Figure S2).

Using this workflow, we characterized the plaque distribution pattern in 2 month-old (mo), 3mo, $4 \mathrm{mo}$, and 6mo App ${ }^{N L-G-F / N L-G-F}$ mice (Fig. 2a). As expected, plaque load in each lamina and subfield increases over time. Plaques begin to appear around 2mo (Fig. 2c-f) and are enriched in the CA1 region of the hippocampus. The dentate gyrus is relatively spared (Fig. 2c, Additional file 3: Figure S3). Plaques are most enriched in the SLM lamina of both CA1 and CA2/3 and in the SO lamina of CA1 (Fig. 2d-e, Additional file 3: Figure S3). In conclusion, we identify some specificity in the distribution of plaques in the hippocampus of $A p p^{N L-G-F}$ knock-in model, with the CA1 subfield and the SLM lamina having the highest plaque load.

\section{Contribution of GABAergic neurons to amyloid pathology in an APP knock-in mouse model}

To determine the contribution of GABAergic neurons to the initial deposition of $A \beta$ plaques, we blocked $A \beta$ production specifically in GABAergic neurons by conditional knock-out of beta-site amyloid precursor protein cleaving enzyme 1 (BACE1) [18] under the control of Glutamate Decarboxylase 2 (Gad2-Cre) in $A p p^{N L-G-F / N L-G-F}$ mice. As validation that Gad2-Cre targets the appropriate cells with high APP-expression, we observed loss of APP 


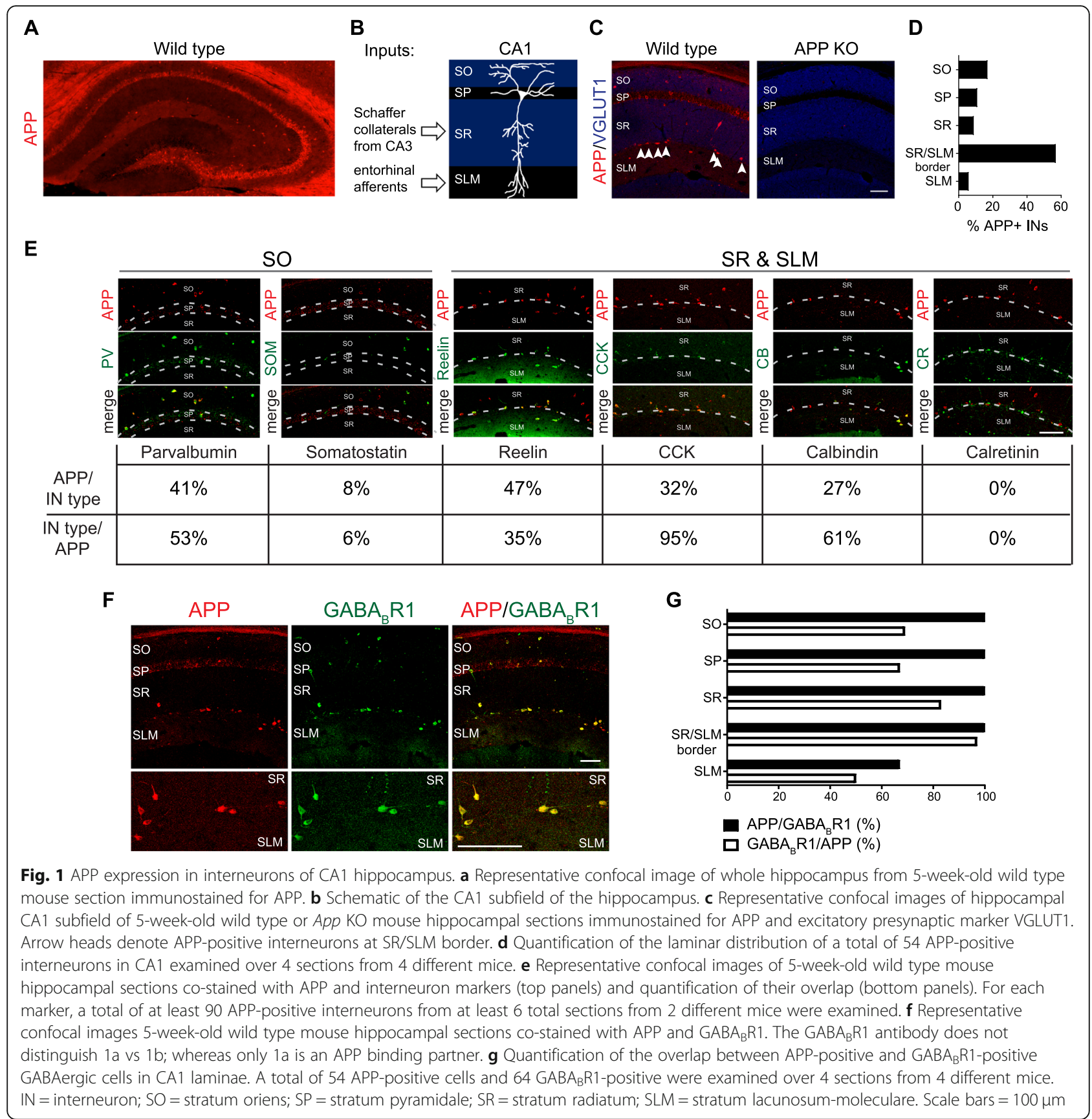

immunoreactivity in $\mathrm{GABA}_{\mathrm{B}} \mathrm{R} 1$-positive interneurons in Aplp2 $2^{-/-}$App ${ }^{\text {flox/flox }}$; Gad2-Cre mice compared to Gad2Cre control mice (Additional file 4: Figure S4). Then, we examined plaque load in the hippocampal subfields and laminae of 3 mo male $A p p^{N L-G-F / N L-G-F}$; Gad2-Cre; Bace1flox/flox mice compared to controls $\left(A p p^{N L-G-F / N L-G-F}\right.$; Gad2-Cre). (Fig. 3a-e), which corresponds to an early stage of plaque deposition (Fig. 2). Plaque load in the whole hippocampus is reduced by $31 \pm 5 \%(n=8$ mice, $p<0.05)$ (Fig. 3b). The strongest reductions in plaque load are observed in the stratum pyramidale (SP) of CA1 and the molecular layer (MO) of the dentate gyrus. While the reduction in plaque load for the entire CA1 subfield is $24 \pm 5 \%$ ( $\mathrm{n}=8$ mice, $p<0.05$ ) (Fig. $3 \mathrm{~b}$ ), the plaque load in the SP of CA1 falls with $75 \pm 5 \%(n=8$ mice, $p<0.05)$ (Fig. $3 c$ ). In the latter area, pyramidal cell bodies and synaptic boutons from perisomatic-targeting interneurons are located. In other areas such as the dentate gyrus or the $\mathrm{MO}$ where granule cell dendrites ramify, plaque load is reduced by $50 \pm 13 \%$ ( $n=8$ mice, $p<0.05$ ) (Fig. 3b) and $50 \pm 14 \%$ ( $n=8$ mice, $p<0.01$ ) (Fig. 3e), respectively. In addition, we biochemically measured $A \beta 42$ by enzyme- 


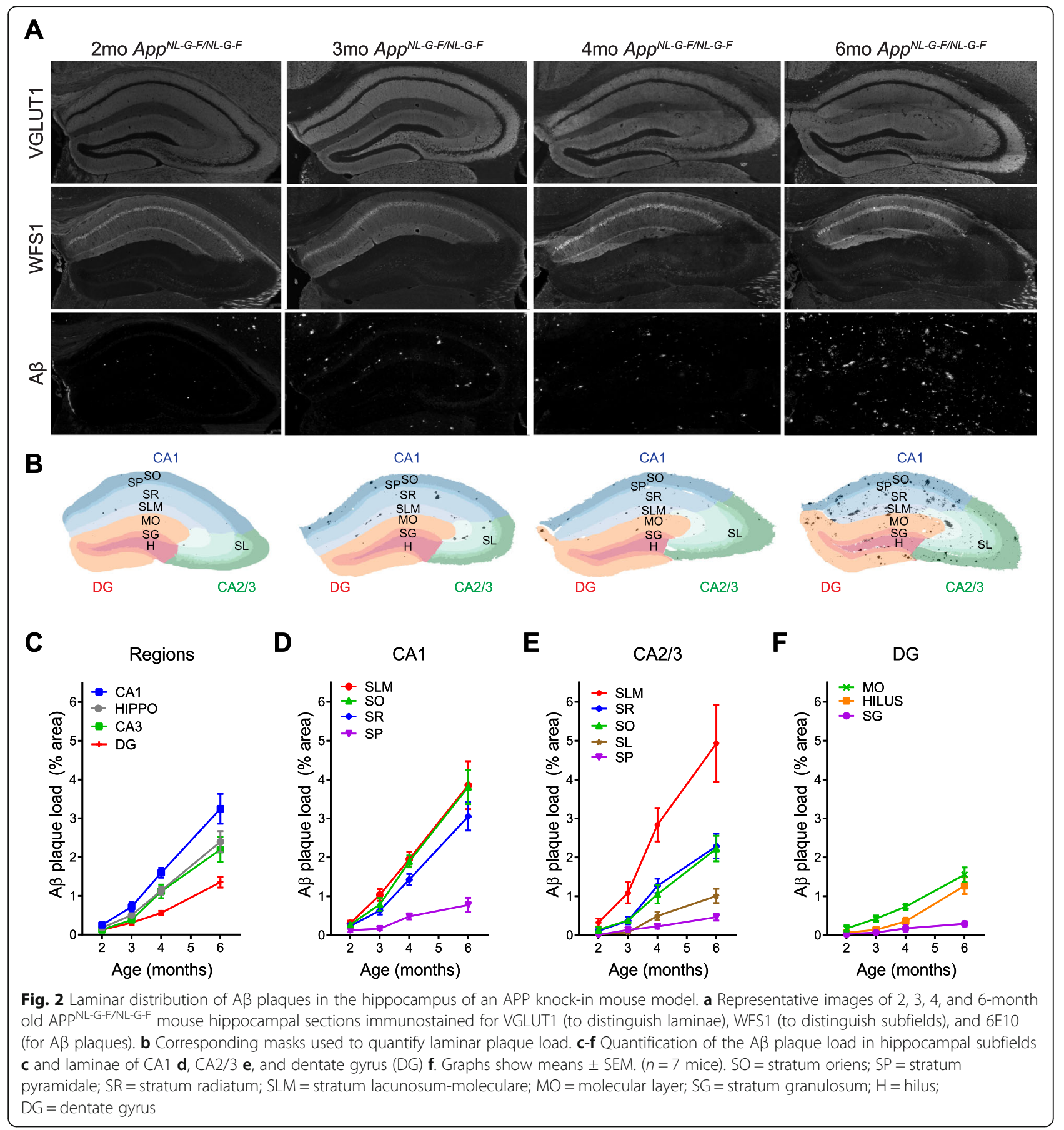

linked immunosorbent assays (ELISA) from the TBS soluble fraction (which represents the soluble nonplaque bound $A \beta$ ) (Fig. 3f) and the insoluble fraction (which represents plaque-bound $A \beta$ ) (Fig. $3 g$ ) of hippocampal homogenates, and a $17 \pm 3 \%(n=12$ mice, $\mathrm{p}<0.01$ ) reduction of $\mathrm{A} \beta 42$ in the soluble fraction was observed. However, during later stages of $A \beta$ deposition, there was not an obvious difference in the plaque load of $6 \mathrm{mo} \quad A p p^{N L-G-F / N L-G-F} ; \quad$ Gad2-Cre; Bace $1^{\text {flox/flox }}$ mice compared to controls (Additional file 5: Figure S5). Taken together, interneurons contribute to approximately $17 \%$ of soluble $A \beta$ and $30 \%$ of the total plaque load in the hippocampus and had the greatest effect on plaque load in the SP of CA1 (75\%) and the MO of the dentate gyrus $(50 \%)$ specifically during early stages of plaque deposition. 


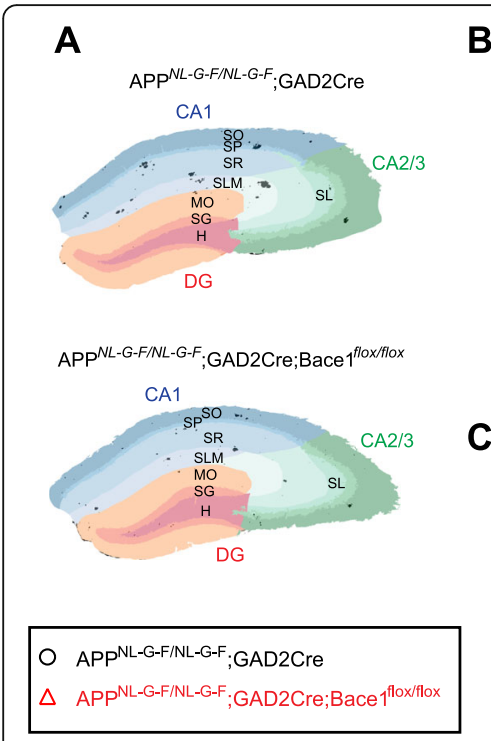

B

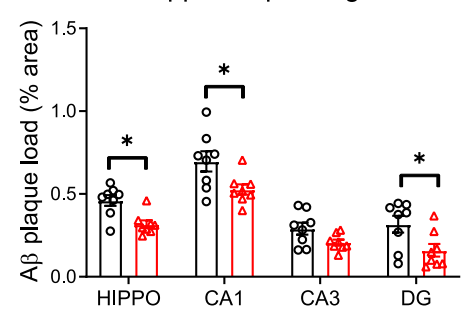

C

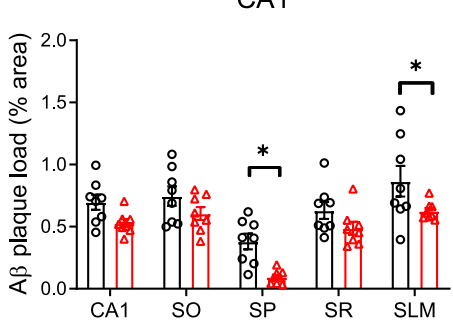

D

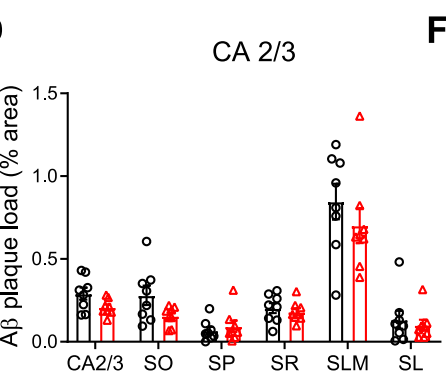

$\mathbf{F}$

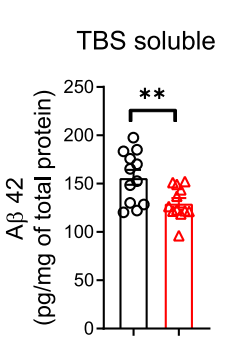

E

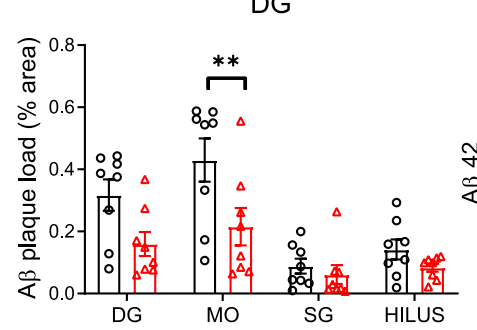

G

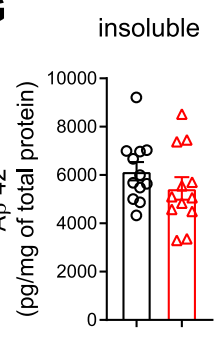

Fig. 3 Contribution of GABAergic neurons to A $\beta$ pathology in an APP knock-in mouse model. a Representative masks generated by IHC to

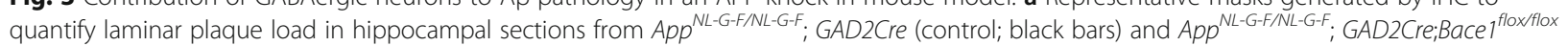
(Bace1CKO in GABAergic neurons; white bars). b-e Quantification of the A 3 plaque load in hippocampal subfields $\mathbf{b}$ and laminae of CA1 c, CA2/3 d, and dentate gyrus (DG) e as determined by IHC. Graphs show means \pm SEM. ( $n=8$ mice; two-way ANOVA) $\mathbf{f}-\mathbf{g}$ Quantification of A 42 measured by ELISA from TBS soluble $\mathbf{f}$ and insoluble $\mathbf{g}$ fractions of hippocampal brain homogenates. ( $n=12$ mice; student's t-test) SO = stratum oriens; $\mathrm{SP}=$ stratum pyramidale; $\mathrm{SR}=$ stratum radiatum; $\mathrm{SLM}=$ stratum lacunosum-moleculare; $\mathrm{MO}=$ molecular layer; $\mathrm{SG}=$ stratum granulosum; $\mathrm{H}=$ hilus; $\mathrm{DG}=$ dentate gyrus. ${ }^{*} P<0.05,{ }^{*} P<0.01$

\section{Discussion}

APP is highly expressed in a subset of GABAergic interneurons in the mouse hippocampus. Parvalbumin, CCK, and Reelin are among the inhibitory neurochemical markers with the greatest overlap with APP-positive cells (Fig. 1e). Interestingly, Reelin interacts with APP $[8,9,21]$. $\mathrm{GABA}_{B} \mathrm{R} 1$, which functionally interacts with the APP ectodomain to regulate presynaptic inhibition $[5,22]$ has strikingly high overlap with the relatively heterogenous population of APP-positive cells. 98\% of APP-positive cells in CA1 are GABA $_{B} R 1$-positive (Fig. 1f-g), which is a much greater overlap than any single neurochemical marker for inhibitory neurons examined (Fig. 1e). These expression patterns may hint at the importance of APP function and interactions in populations of GABAergic interneurons. Indeed, GABAergic inhibition and short-term plasticity of GABAergic inputs are impaired with genetic loss of APP $[25,31,33]$.

This expression pattern of APP is not expected to be maintained in APP transgenic mouse models but would differ between models depending on the promoter and integration site [10]. Expression of the APP transgene in interneurons has been best studied in the Tg2576 model [11]. While there is prominent APP expression in interneurons of Tg2576 mice, the neurochemical profile of APP-interneurons does not match the profile we found here for endogenous APP. For example, high proportions of somatostatin cells are APP immunereactive in the Tg2576 mice [11]; whereas we observe almost no overlap of APP with somatostatin cells.

We developed a novel method to analyze plaque load with high spatial resolution of hippocampal laminae and subfields in the $A p p^{N L-G-F}$ knock-in mouse model of AD (Additional file 2: Figure S2). Comparing across subfields we found that $A \beta$ plaques are enriched in the CA1 region of the hippocampus compared to the total hippocampus, and the dentate gyrus is relatively spared. This is contrary to APP overexpressing models of AD, in which plaques are enriched in the dentate gyrus $[1,3,17,20,32]$. Within the CA1 subfield, we found that the SO and SLM had the highest plaque load in $A p p^{N L-G-F}$ mice.

We determined the contribution of GABAergic neurons to amyloid pathology by blocking $A \beta$ production by cell type-specific knock-out of BACE1. This resulted in an overall $30 \%$ reduction in total plaque load and $17 \%$ reduction in soluble $A \beta$ in the hippocampus. Since GABAergic interneurons are estimated to account for only $10-15 \%$ of the total neurons in the hippocampus [19], our findings suggest that GABAergic interneurons, on a per cell basis, contribute at least proportionally to to $\mathrm{A} \beta$ production in the hippocampus of $A p p^{N L-G-F}$ mice. Possible mechanisms leading to robust secretion of $\mathrm{A} \beta$ from interneurons include high-APP expression (Fig. 1) as well as high firing rates of interneurons 
relative to excitatory neurons $[7,13]$, since synaptic activity has been shown to promote $A \beta$ generation $[4,12]$. Notably, we found that BACE1 knock-out in GABAergic neurons resulted in the greatest reduction (75\%) in plaque load in the SP of CA1, where axon terminals of basket-cell interneurons form elaborate basket-like structures on and around the pyramidal cells bodies. These basket-cell interneurons include CCK and Parvalbumin interneurons [19], both of which have high overlap with APP-positive cells. Interestingly, Parvalbumin is known to label highly active 'fast-spiking' interneurons, and deficits in Parvalbumin interneurons have been linked to altered network activity in an AD mouse model [30]. Together, our findings reveal a crucial role of GABAergic interneurons in the pathology of AD, particularly in the SP layer of the CA1 hippocampus where plaques in human $\mathrm{AD}$ cases are most prevalent [6]. Thus, therapies that modulate activity of GABAergic interneurons could have profound effects on AD pathology.

\section{Methods}

\section{Animals}

All animal experiments were conducted according to the KU Leuven ethical guidelines and approved by the KU Leuven Committee on Animal Care. Generation of the

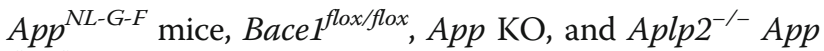
floxflox mice were described previously $[2,15,18,23]$. GAD2Cre mice were obtained from Jackson Laboratory (Jax 010802). Both male and female $A p p^{N L-G-F}$ were used in the time course experiments in Fig. 2. Only male mice were used in Fig. 3.

\section{Histology \& Immunohistochemistry}

Mice were transcardially perfused with $5 \mathrm{~mL}$ of saline solution followed by $10 \mathrm{~mL}$ of $4 \%$ PFA in PBS. Brains were dissected, post-fixed for $1 \mathrm{~h}$ at $4{ }^{\circ} \mathrm{C}$ with $4 \%$ PFA, and then incubated in $30 \%$ sucrose solution. Brains were embedded in OCT (Sakura-Tissue-Tek, 4583) and frozen in isopentane. 16um coronal sections were generated using a cryostat (Nx70, ThermoFisher).

16um coronal sections were post-fixed in 1:1 ice-cold $\mathrm{MeOH}$-Acetone for $10 \mathrm{~min}$, washed with $\mathrm{PBS}$ and $0.5 \%$ Triton X-100 in PBS (PBS-T), and blocked in PBS-gelatin containing 10\% NHS, 1:43 Donkey anti-mouse Fab frabment (Jackson ImmunoResearch, 715-007-003), and 0.5\% Triton X-100 for $2 \mathrm{~h}$. Samples were then incubated overnight at $4{ }^{\circ} \mathrm{C}$ with primary antibodies in PBS-gelatin containing 5\% NHS and $0.5 \%$ Triton X-100. Primary antibodies included the following: mouse anti-6E10 (1: 1000, BioLegend, 803,003), rabbit anti-WFS1 (1:600, ProteinTech, 11,558-1-AP), guinea pig anti-vGLUT1 (1:5000, Millipore, AB5905), rabbit anti-APP $(1: 10,000$, B63, cterminal,), mouse anti-Parvalbumin (1:1000, Swant, 235), rat anti-somatostatin (1:500, Millipore, MAB354), mouse
anti-Reelin (1:500, CR50, MBL International, D223-3,), mouse anti-CCK (1:250, AbCam, ab37274), mouse antiCalbindin (1:2500, Swant, 300), guinea pig anti-Calretinin (Calbindin D29k) (1:1000, Synaptic Systems, 214,104), mouse anti-GABABR1 (1:500, NeuroMab, 75-183,). Samples were subsequently washed in $0.5 \%$ PBS- $\mathrm{T}$ and incubated with secondary antibodies in PBS-gelatin containing $5 \%$ NHS and $0.5 \%$ Triton $\mathrm{X}-100$, for $2 \mathrm{~h}$ at room temperature. Coverslips were mounted using Mowiol mounting medium. Sections were imaged using Leica confocal microscopes (SP5 and SP8) for imaging of interneurons or the Axio Scan.Z1 Slide Scanner (ZEISS) with 20X objective for $A \beta$ plaque analysis.

\section{Image processing}

For quantification of immune-positive cells by IHC: Using ImageJ software, vGLUT1 staining was used to segment hippocampal layers. Manual thresholding was performed and the automatic "Wand (Tracing) Tool" was used to select immunopositive cells and generate masks. Accordingly, APP positive cells are defined as cells with APP immunolabeling above threshold.

For quantification of $\mathrm{A} \beta$ plaque load by IHC: Using the ZEN software, single hippocampi were selected and images were exported as TIFF files (8bit, LWZ compression, scalebar). Exported TIFF files were then analyzed using the ImageJ software. Images with vGLUT1 staining were used to segment the hippocampal layers. A manual threshold was applied, and the stratum pyramidale (SP) and stratum granulosum (SG) layers were selected using the automatic "Wand (Tracing) Tool", while the whole hippocampus was either automatically selected, or manually defined using the "Selection Brush Tool". Then, the remaining hippocampal laminae were manually segmented. Using the WFS1-staining images, ROIs were refined to separate the Cornu Ammonis (CA) 1 and 2/3 hippocampal subfields. After ROIs were defined, $6 \mathrm{E} 10$-staining images were used to create a mask for $\mathrm{A} \beta$ plaques. For the $A \beta$ plaque-mask, an automatic threshold was applied (threshold name: "Triangle"), and the particles with size $>10 \mu \mathrm{m}^{\wedge} 2$ were considered for the mask creation. Finally, ROIs were applied on top of the $\mathrm{A} \beta$ plaque-mask and measurements were analyzed per layer for "Area" (area of each layer) and "Area Faction" (fraction covered by plaques).

\section{$A \beta$ extraction and ELISA}

Mice were transcardially perfused with saline, and hippocampi were dissected and flash-frozen. Hippocampi were mechanically homogenized using Fastprep tubes and T-PER Tissue Protein Extraction Reagent (Thermo Fisher Scientific, 78,510) with phosphatase inhibitors (Merck, P0044 and P5726) and cOmplete protease inhibitors (Roche, 11,836,145,001). The TBS soluble 
fraction was collected as the supernatant after ultracentrifugation $\left(1 \mathrm{~h}, 4{ }^{\circ} \mathrm{C}, 55000 \mathrm{rpm}\right.$; TLA 100.4 rotor, Beckman Coulter). For the insoluble fraction, the pellet was resuspended in 2 volumes (vol: wet weight of tissue) of $\mathrm{GuHCl}(6 \mathrm{M}$ GuHCl$/ 50 \mathrm{mM}$ Tris-HCl, $\mathrm{pH} 7.6)$ with cOmplete protease inhibitors and sonicated for 30s. After $1 \mathrm{~h}$ incubation at $25^{\circ} \mathrm{C}$ followed by ultracentrifugation $\left(20 \mathrm{~min}, 70.000 \mathrm{rpm}, 4^{\circ} \mathrm{C}\right.$; TLA 100.4 rotor, Beckman Coulter), the supernatant was diluted $12 \mathrm{X}$ in $\mathrm{GuHCl}$ diluent buffer ( $20 \mathrm{mM}$ phosphate, $0.4 \mathrm{M} \mathrm{NaCl}, 2$ mM EDTA, 10\% Block Ace, 0.2\% BSA, 0.0\% NaN3, $0.075 \%$ CHAPS, $\mathrm{pH} 7.0$ ) with cOmplete protease inhibitors. A 442 levels were quantified on MSD single spot 96 well plates in house coated overnight with JRF A $\beta 42 / 26$ antibody at $1,5 \mu \mathrm{g} / \mathrm{ml}$ in PBS. Plates were rinsed $5 \mathrm{x}$ with $200 \mu \mathrm{l} /$ well washing buffer (PBS $+0.05 \%$ Tween-20), blocked with $150 \mu \mathrm{l} /$ well $0.1 \%$ casein buffer for $1.5 \mathrm{~h}$ at room temperature $(600 \mathrm{rpm})$ and rinsed $5 \mathrm{x}$ with $200 \mu \mathrm{l} /$ well washing buffer. $25 \mu \mathrm{l}$ of SULFO-TAG JRF/AbN/25 detection antibody diluted in blocking buffer was mixed with $25 \mu \mathrm{l}$ of standards (synthetic human A $\beta 1-42$ peptide) or reaction samples diluted in blocking buffer $(1 / 2$ dilution for soluble $A \beta$-fraction and $1 / 250$ for insoluble $\mathrm{A} \beta$-fraction) and loaded $50 \mu \mathrm{l}$ per well. After overnight incubation at $4{ }^{\circ} \mathrm{C}$, plates were rinsed with washing buffer and $150 \mu \mathrm{l} /$ well of the 2x MSD Read Buffer T (trisbased buffer containing tripropylamine, purchased from Meso Scale Discovery) was added. Plates were immediately read on MSD Sector Imager 6000.

\section{RNAscope in situ hybridization}

$16 \mu \mathrm{m}$ coronal hippocampal cryosections were obtained from flash-frozen, 5 week old C57BL/6 and App KO mouse brains. RNAscope in situ hybridization was performed using the Fluorescent Multiplex Reagent Kit (Advanced Cell Diagnostics, 320,850) following manufacturer's protocol. Heating steps were performed using the HybEZTM oven (Advanced Cell Diagnostics). Sections were pretreated with Pretreat 4 reagent and hybridized with the following probes: Mm-Slc17a7 (416631), Mm-App-XHs-C2 (519001), Mm-Slc32a1-C3 (319191). After amplification steps, sections were mounted using Prolong Gold Antifade (ThermoScientific). Imaging was performed using a slidescanner microscope (Zeiss Axioscan.Z1) with a 20X air objective. Image processing was performed in ZEN 2.3 lite and FIJI.

\section{Supplementary information}

Supplementary information accompanies this paper at https://doi.org/10. 1186/s13024-019-0356-y.

Additional file 1: Figure S1. APP mRNA expression in excitatory and inhibitory neurons of the hippocampus. Fluorescent in situ hybridization for App (red), the inhibitory neuron marker Vgat (green) and the excitatory neuron marker Vglut 1 (blue) mRNAs in wild type and APP KO coronal sections. Insets show CA1 region. Scalebar is $100 \mu \mathrm{m}$.

Additional file 2: Figure S2. Workflow for quantification of $A \beta$ plaque load across hippocampal laminae. Outline of methods developed to quantify $A \beta$ load across hippocampal laminae by segmenting hippocampal laminae, refining hippocampal subfields, creating masks to define $A \beta$ plaque area, and combing the regions of interest (ROIs) for each subfield and laminae with masks for $A \beta$ plaque area.

Additional file 3: Figure S3. Laminar distribution of $A \beta$ plaques in the hippocampus of APP knock-in mice. Graphs detailing the data summarized in Fig. 2c-f. Quantification of the AB plaque load in hippocampal subfields and laminae of CA1, CA2/3 and dentate gyrus (DG) of sections from 2, 3, 4, and 6 month old APP NL-G-F/NL-G-F mice. Graphs show means \pm SEM. $(n=5-7$ mice; one-way ANOVA). ${ }^{*} P<0.05$, ${ }^{* *} P<0.01$, ${ }^{*} P<0.001 \mathrm{SO}=$ stratum oriens; $\mathrm{SP}=$ stratum pyramidale; $\mathrm{SR}=$ stratum radiatum; $\mathrm{SLM}=$ stratum lacunosummoleculare; $\mathrm{MO}=$ molecular layer; $\mathrm{SG}=$ stratum granulosum; $\mathrm{H}=$ hilus; $\mathrm{DG}=$ dentate gyrus.

Additional file 4: Figure S4. LOSS of APP immunoreactivity in GABABR1-positive interneurons in Aplp2 ${ }^{-/-}$App $^{\text {flox/flox; }}$ Gad2-Cre mice. Representative confocal images of mouse hippocampal sections of Aplp2 $2^{-1-}$ App flox/flox; Gad2-Cre.

Additional file 5: Figure S5. Plaque load of $6 \mathrm{mo}$ App ${ }^{\mathrm{NL}-G-F / N L-G-F} ; \mathrm{Gad}_{2}$ Cre; Bace $1^{\text {flox/flox }}$ mice compared to controls. Quantification of the $A \beta$ plaque load in hippomcapus as determined by IHC. Graphs show means \pm SEM. ( $n=3$ mice).

\section{Abbreviations}

AD: Alzheimer's disease; APP: Amyloid Precursor Protein; A $\beta$ : amyloid- $\beta$; BACE1: beta-site amyloid precursor protein cleaving enzyme 1; CA1: Cornu Ammonis 1; CCK: Cholecystokinin; DG: dentate gyrus; ELISA: Enzyme-linked

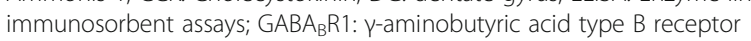
subunit 1; Gad2: Glutamate Decarboxylase 2; H: Hilus; MO: Molecular layer; mo: Month-old; SG: Stratum granulosum; SLM: Stratum lacunosummoleculare; SO: Stratum oriens; SP: Stratum pyramidale; SR: Stratum radiatum

\section{Acknowledgements}

We thank Véronique Hendrickx and Jonas Verwaeren for assistance with the mouse colonies.

\section{Authors' contributions}

$H C R, J d W$, and BDS designed the study, supervised the experiments, and wrote the manuscript. HCR, GM, and IC performed histology, IHC, image processing, and data analysis. GM performed RNAscope and developed macros for image processing. KH performed A $\beta$ extractions and ELISA. TYP provided Aplp2 ${ }^{-1-}$ App flox/flox mice. UCM provided APP KO mice. TS and TCS provided App ${ }^{N L-G-F}$ mice. RV provided BACE1 CKO mice. All authors read and approved the final manuscript.

\section{Funding}

This work was supported by an Alzheimer's Association Research Fellowship (AARF-16-442885, H.C.R.); the Stichting Alzheimer Onderzoek (SAO) Pilot Grant (16011, H.C.R.); ERC Starting Grant (311083, J.d.W.); the Fund for Scientific Research, Flanders (FWO) Odysseus Grant (J.d.W.); FWO Project Grant G.0654.15 N (J.d.W.); FWO Project Grant G.0D98.17 N (B.D.S.); a Methusalem grant from the KU Leuven (B.D.S. and J.d.W.); ERC advanced Grant (268675, B.D.S); The Flemish Government and Vlaams Initiatief voor Netwerken voor Dementie Onderzoek (VIND) Strategic Basic Research Grant 135043 (B.D.S).; B.D.S. is supported by the Arthur Bax and Anna Vanluffelen chair for Alzheimer's disease, "Opening the Future" of the Leuven University Fund (LUF) and the Queen Elisabeth Medical Foundation for Neurosciences (GSKE).

\section{Availability of data and materials}

Raw data is available from the corresponding authors upon reasonable request.

Ethics approval and consent to participate

All animal experiments were conducted according to the KU Leuven ethical guidelines and approved by the KU Leuven Committee on Animal Care. 


\section{Consent for publication}

Not applicable.

\section{Competing interests}

The authors declare that they have no competing interests. BDS has received consulting fees and support from Janssen pharmaceutica.

\begin{abstract}
Author details
${ }^{1}$ VIB Center for Brain \& Disease Research, Leuven, Belgium. ${ }^{2}$ Department of Neurosciences, Leuven Brain Institute, KU Leuven, Leuven, Belgium. ${ }^{3}$ resent Address: Department of Biochemistry and Molecular Biology, Oklahoma Center for Geroscience, University of Oklahoma Health Sciences Center, Oklahoma City, OK, USA. ${ }^{4}$ Department of Neurology, Ann Romney Center for Neurologic Diseases, Brigham and Women's Hospital and Harvard Medical School, Boston, MA, USA. ${ }^{5}$ Department of Functional Genomics, Institute of Pharmacy and Molecular Biotechnology, Heidelberg University, Heidelberg, Germany. 'Laboratory for Proteolytic Neuroscience, RIKEN Center for Brain Science, Saitama, Japan. ${ }^{7}$ Department of Neurocognitive Science, Nagoya City University Graduate School of Medical Science, Nagoya, Japan. ${ }^{8}$ Department of Neurology, Feinberg School of Medicine, Northwestern University, Chicago, USA. ${ }^{9}$ UK-Dementia Research Institute at University College London, London, UK.
\end{abstract}

\section{Received: 12 December 2019 Accepted: 30 December 2019}

Published online: 08 January 2020

\section{References}

1. Alonso-Nanclares L, Merino-Serrais P, Gonzalez S, DeFelipe J. Synaptic changes in the dentate gyrus of APP/PS1 transgenic mice revealed by electron microscopy. J Neuropathol Exp Neurol. 2013;72:386-95.

2. Callahan DG, Taylor WM, Tilearcio M, Cavanaugh T, Selkoe DJ, Young-Pearse TL. Embryonic mosaic deletion of APP results in displaced Reelin-expressing cells in the cerebral cortex. Dev Biol. 2017:424:138-46.

3. Chapman PF, Hsiao K, White GL, Jones MW, Cooper-Blacketer D, Marshall VJ, Irizarry M, Younkin L, Good MA, Bliss TVP, et al. Impaired synaptic plasticity and learning in aged amyloid precursor protein transgenic mice. Nat Neurosci. 1999:2:271-6.

4. Cirrito JR, Yamada KA, Finn MB, Sloviter RS, Bales KR, May PC, Schoepp DD Paul SM, Mennerick S, Holtzman DM. Synaptic activity regulates interstitial fluid amyloid-beta levels in vivo. Neuron. 2005;48:913-22

5. Dinamarca MC, Raveh A, Schneider A, Fritzius T, Früh S, Rem PD, Stawarsk M, Lalanne T, Turecek R, Choo M, et al. Complex formation of APP with GABA $B$ receptors links axonal trafficking to amyloidogenic processing. Nat Commun. 2019:10(1):1331.

6. Furcila D, Defelipe J, Alonso-Nanclares L. A study of amyloid- $\beta$ and Phosphotau in plaques and neurons in the Hippocampus of Alzheimer's disease patients. J Alzheimers Dis. 2018;64:417-35.

7. Hájos N, Pálhalini J, Mann EO, Nèmeth B, Paulsen O, Freund TF. Spike timing of distinct types of GABAergic interneuron during hippocampal gamma oscillations in vitro. J Neurosci. 2004:24:9127-37.

8. Hoe HS, Tran TS, Matsuoka Y, Howell BW, Rebeck GW. DAB1 and reelin effects on amyloid precursor protein and ApoE receptor 2 trafficking and processing. J Biol Chem. 2006:281:35176-85.

9. Hoe HS, Lee KJ, Carney RS, Lee J, Markova A, Lee JY, Howell BW, Hyman BT, Pak DT, Bu G, et al. Interaction of reelin with amyloid precursor protein promotes neurite outgrowth. J Neurosci. 2009;29:7459-73.

10. Höfling C, Morawski M, Zeitschel U, Zanier ER, Moschke K, Serdaroglu A, Canneva F, von Hörsten S, De Simoni MG, Forloni G, et al. Differential transgene expression patterns in Alzheimer mouse models revealed by novel human amyloid precursor protein-specific antibodies. Aging Cell. 2016;15:953-63.

11. Höfling C, Shehabi E, Kuhn PH, Lichtenthaler SF, Hartlage-Rübsamen M, Roßner S. Cell type-specific human APP transgene expression by hippocampal interneurons in the TG2576 mouse model of Alzheimer's disease. Front Neurosci. 2019;13:1-12.

12. Kamenetz F, Tomita T, Hsieh H, Seabrook G, Borchelt D, Iwatsubo T, Sisodia S, Malinow R. APP processing and synaptic function. Neuron. 2003;37:925-37.

13. Kawaguchi Y. Distinct Firing Patterns of Neuronal Subtypes in Cortical Synchronized Activities. J Neurosci. 2001;21:7261-72.

14. Li Y, Sun $H_{1}$ Chen $Z$, Xu H, Bu G, Zheng $H$. Implications of GABAergic neurotransmission in Alzheimer's disease. Front Aging Neurosci. 2016;8:1-12.
15. Li ZW, Stark G, Gotz J, Rulicke T, Gschwind M, Huber G, Muller U, Weissmann C. Generation of mice with a 200-kb amyloid precursor protein gene deletion by Cre recombinase-mediated site-specific recombination in embryonic stem cells. Proc Natl Acad Sci. 2002;93:6158-62.

16. Liao M-C, Muratore CR, Gierahn TM, Sullivan SE, Srikanth P, De Jager PL, Love JC, Young-Pearse TL. Single-cell detection of secreted Abeta and SAPP from human IPSC-derived neurons and astrocytes. J Neurosci. 2016;36:1730-46.

17. Mucke L, Masliah E, Yu GQ, Mallory M, Rockenstein EM, Tatsuno G, Hu K Kholodenko D, Johnson-Wood K, McConlogue L. High-level neuronal expression of abeta 1-42 in wild-type human amyloid protein precursor transgenic mice: synaptotoxicity without plaque formation. J Neurosci. 2000; 20:4050-8.

18. Ou-Yang MH, Kurz JE, Nomura T, Popovic J, Rajapaksha TW, Dong H, Contractor A, Chetkovich DM, Tourtellotte WG, Vassar R. Axonal organization defects in the hippocampus of adult conditional BACE1 knockout mice. Sci Transl Med. 2018;10(459):eaao5620.

19. Pelkey KA, Chittajallu R, Craig MT, Tricoire L, Wester JC, McBain CJ. Hippocampal GABAergic inhibitory interneurons. Physiol Rev. 2017;97:1619747.

20. Reilly JF, Games D, Rydel RE, Freedman S, Schenk D, Young WG, Morrison $\mathrm{JH}$, Bloom FE. Amyloid deposition in the hippocampus and entorhinal cortex: quantitative analysis of a transgenic mouse model. Proc Natl Acad Sci. 2003;100:4837-42.

21. Rice HC, Young-pearse TL, Selkoe DJ. Systematic evaluation of candidate ligands regulating Ectodomain shedding of amyloid precursor protein. Biochemistry. 2013:52:3264-77.

22. Rice HC, De Malmazet D, Schreurs A, Frere S, Van Molle I, Volkov AN, Creemers E, Vertkin I, Nys J, Ranaivoson FM, et al. Secreted amyloid-b precursor protein functions as a GABA B R1a ligand to modulate synaptic transmission. Science. 2019;363(6423):eaao4827.

23. Saito T, Matsuba Y, Mihira N, Takano J, Nilsson P, Itohara S, Iwata N, Saido TC. Single app knock-in mouse models of Alzheimer's disease. Nat Neurosci. 2014;17:661-3.

24. Sasaguri H, Nilsson P, Hashimoto S, Nagata K, Saito T, De Strooper B, Hardy J, Vassar R, Winblad B, Saido TC. APP mouse models for Alzheimer's disease preclinical studies. EMBO J. 2017;36:e201797397.

25. Seabrook GR, Smith DW, Bowery BJ, Easter A, Reynolds T, Fitzjohn SM Morton RA, Zheng H, Dawson GR, Sirinathsinghji DJS, et al. Mechanisms contributing to the deficits in hippocampal synaptic plasticity in mice lacking amyloid precursor protein. Neuropharmacology. 1999;38:349-59.

26. Sloviter RS, Ali-Akbarian L, Elliott RC, Bowery BJ, Bowery NG. Localization of $\mathrm{GABA}(\mathrm{B})(\mathrm{R} 1)$ receptors in the rat hippocampus by immunocytochemistry and high resolution autoradiography, with specific reference to its localization in identified hippocampal interneuron subpopulations. Neuropharmacology. 1999:38:1707-21.

27. De Strooper B, Karran E. The cellular phase of Alzheimer's disease. Cell. 2016; 164:603-15

28. Del Turco D, Paul MH, Schlaudraff J, Hick M, Endres K, Müller UC, Deller T. Region-specific differences in amyloid precursor protein expression in the mouse Hippocampus. Front Mol Neurosci. 2016;9:1-12.

29. Veeraraghavalu K, Zhang C, Zhang X, Tanzi RE, Sisodia SS. Age-dependent, non-cell-autonomous deposition of amyloid from synthesis of beta-amyloid by cells other than excitatory neurons. J Neurosci. 2014;34:3668-73.

30. Verret L, Mann EO, Hang GB, Barth AMI, Cobos I, Ho K, Devidze N, Masliah E, Kreitzer AC, Mody I, et al. Inhibitory interneuron deficit links altered network activity and cognitive dysfunction in alzheimer model. Cell. 2012;149:70821.

31. Wang B, Wang Z, Sun L, Yang XL, Li H, Cole AL, Rodriguez-rivera J, Lu H, Zheng $\mathrm{H}$. The amyloid precursor protein controls adult hippocampal neurogenesis through GABAergic interneurons. J Neurosci. 2014;34:1331425.

32. Wu Z, Guo Z, Gearing M, Chen G. Tonic inhibition in dentate gyrus impairs long-term potentiation and memory in an Alzhiemer's disease model. Nat Commun. 2014:5:1-12

33. Yang L, Wang Z, Wang B, Justice NJ, Zheng H. Amyloid precursor protein regulates Cav1.2 L-type calcium channel levels and function to influence GABAergic short-term plasticity. J Neurosci. 2009;29:15660-8.

\section{Publisher's Note}

Springer Nature remains neutral with regard to jurisdictional claims in published maps and institutional affiliations. 